\title{
酸化グラフェンナノシート懸濁液による抵抗減少効果と熱伝達特性
}

\author{
小方 聡*1，仁科 勇太 ${ }^{* 2}$, 栃木 弘 $^{* 3}$ ，渡辺 敬三*4
}

\section{Drag reduction and heat transfer characteristics of graphene oxide nanosheet suspensions}

\author{
Satoshi OGATA $^{* 1}$, Yuta NISHINA ${ }^{* 2}$, Hiroshi TOCHIGI ${ }^{* 3}$ and Keizo WATANABE ${ }^{* 4}$ \\ ${ }^{* 1, * 4}$ Department of Mechanical Systems Engineering, Tokyo Metropolitan University \\ 1-1 Minami-Osawa, Hachioji-shi, Tokyo 192-0397, Japan \\ ${ }^{* 2}$ Research Core for Interdisciplinary Sciences, Okayama University \\ 3-1-1 Tsushimanaka, Okayama-shi, Okayama 700-8530, Japan \\ ${ }^{* 3}$ Cosmo Oil Lubricants Co., LTD. \\ 1134-2 Gongendo, Satte-shi, Saitama 340-0193, Japan
}

Received: 17 February 2020; Revised: 23 March 2020; Accepted: 19 April 2020

\begin{abstract}
This study investigated graphene oxide nanosheets, with excellent thermal conductivity and water dispersibility, as additives that could achieve a trade-off relationship between drag reduction and heat transfer improvement. We experimentally clarified the heat flow characteristics of graphene oxide nanosheet suspensions in a circular pipe. The graphene oxide nanosheets have a size of $0.8 \mathrm{~nm} \times 3 \mu \mathrm{m} \times 3 \mu \mathrm{m}$. The test suspension concentrations were $0.1 \mathrm{wt} \%, 0.3 \mathrm{wt} \%$, and $0.5 \mathrm{wt} \%$. For a comparison, a $0.5 \mathrm{wt} \% \mathrm{TiO}_{2}$ suspension showing an improvement in the heat transfer coefficient and a $15 \mathrm{ppm}$ Peo solution with drag reduction were also prepared. The experimental results show that the frictional coefficient of the graphene oxide nanosheet suspensions was reduced by up to $36.5 \%$ compared to that of distilled water in the turbulent flow region. The amount of drag reduction increased with the increase of Reynolds number. After reaching the maximum value, it gradually approached a constant value. Meanwhile, the Nusselt number of the graphene oxide nanosheet suspensions increased by $10-20 \%$ in the range of the Reynolds number where the drag reduction occurred. This result indicates that the nanosheets improved the heat transfer performance, which increased with increasing concentration and Reynolds number. In conclusion, improvements in both drag reduction and heat transfer cannot be achieved in the $\mathrm{TiO}_{2}$ suspension and Peo solution, but these properties were found in the graphene oxide nanosheet suspensions used herein.
\end{abstract}

Keywords : Circular pipe flow, Pressure drop, Heat transfer, Drag reduction, Graphene oxide suspension

\section{1. 緒言}

近年，効率的な熱エネルギーの管路内輸送手段の一つとして，輸送媒体に抵抗低減効果を有する流体を利用す る試みが注目されている（Shi et al., 2013）（Gasljevic and Matthys, 1996）。特に，配管の圧力損失の低減はプラント や地域冷暖房などの比較的大きい装置だけでなく，ビルなどの空調の温水冷水循環を担うポンプのランニングコ ストの低下に直結し，エネルギーの大幅な削減が期待できる。さらに，流体摩擦抵抗の低減化技術の開発は，流 体流動が関連する様々な機器の効率向上や小型化にも繋がるなどの利点もある. この流動抵抗を低減させる方法 は種々考えられるが, 抵抗低減添加剤を溶媒に添加する方法は, その低減量が他の方法と比較して非常に大きく, また既存の流路を改良する必要がなくコストを安くすることが可能である．抵抗低減する添加剤の代表的なもの

No.20-00047 [DOI:10.1299/transjsme.20-00047], J-STAGE Advance Publication date : 27 April, 2020

*1 正員，東京都立大学 システムデザイン学部（†192-0397＼cjkstart東京都八王子市南大沢 1-1）

*2 岡山大学 異分野融合先端研究コア (₹700-8530 岡山県岡山市北区津島中 3-1-1)

*3 コスモ石油ルブリカンツ（†340-0193 埼玉県幸手市権現堂 1134-2）

*4 正員, 名誉員, 東京都立大学 システムデザイン学部

E-mail of corresponding author: ogata-satoshi@tmu.ac.jp 
としては，水溶性ポリマー（Toms, 1949）（White and Mungal, 2008），界面活性剤（Zakin et al., 1998），繊維（Cui and Grace, 2007）などが研究されている.

これら抵抗低減添加剤は管内乱流渦の発生や発達を抑制することで流動抵抗の減少をもたらすものとして知ら れている.しかしながら，このような抵抗低減添加剤を熱交換器などの熱と流動が同時に発生する機器に適用し た場合,「レイノルズのアナロジー」として知られているように抵抗低減を得ることと同時に熱伝達率も同程度低 減してしまう（Li et al., 2004, 2012）。このことは, 熱交換器に代表される熱と流動が同時に発生する流体機械の性 能向上を妨げる要因の一つになっている，よって，その高効率化を実現するためには，抵抗低減流体を流用した 際に生じる熱伝達低減を解決することが非常に重要である.

一方，現在，熱伝導特性や潤滑特性の向上を目的としてナノ粒子䀣濁液の流動が粒目されている.ナノ粒子は 粒子径が $100 \mathrm{~nm}$ 以下と非常に小さく活性度や反応性が高い.さらに，ナノ粒子懸濁液は水やオイルなどと比較 して高い熱伝導特性を持つ（Ganvir et al., 2017）。流動場に関して Bhanvase ら（Bhanvase et al., 2014）は，水/エチ レングリコールがベースの流体に $0.1 \sim 0.5 \mathrm{vol} \%$ の $\mathrm{TiO}_{2}$ ナノ粒子を分散させた懸濁液は層流域でベースの流体と 比較して熱伝達率が $105 \%$ も増加することを報告している. このような伝熱性能の向上はカーボンナノチューブ 懸濁液でも報告されているが（Sarafraz and Hormozi, 2016），ナノ粒子懸濁液は単相流と比較して層流域および乱 流域で圧力損失は増加する，一般的には，ナノ粒子添加はベース流体と比較して熱伝達特性が向上するが，同時 に圧力損失は増加の傾向にあると言える.

このようなナノ粒子や抵抗低減流体の両者の欠点を克服する手法として, Wang ら（Wang et al., 2017）は，平均 粒子径 $30 \mathrm{~nm}$ の $\mathrm{CuO}$ ナノ粒子を CTAC（塩化セチルトリメチルアンモニウム）溶液に懸濁させた流体を用いて 抵抗低減および熱伝達特性の測定を行っており，4 wt％の懸濁液は CTAC 溶液の抵抗低減効果を維持したまま熱 伝達率を増加させ， $100 \mathrm{ppm}$ の溶液に添加した場合約 40\%増加させることを明らかにした。この結果は乱流域で 抵抗低減効果を有寸る CTAC の欠点である熱伝達低減をナノ粒子添加で補おうとした研究であるが，ナノ粒子単 体でそれらを実現できる添加剤は現在のところ存在しないようである.

本研究では, このトレードオフの関係にある抵抗低減と熱伝達向上を達成する添加剤として, 熱伝導性および 水分散性に優れる酸化グラフェンナノシート（Kinoshita et al., 2014）に着目した. 酸化グラフェンはカーボンの単 相シートであるグラフェンが酸化したもので，炭素原子 1 個分ほどの厚さの 2 次元シート状の物質である. また 機械的強度が高く，比較的安価であるため様々な工業分野への応用が期待されている．また，通常ナノ材料では 凝集性が非常に高く, 液中では凝集してしまうが，酸化グラフェンではカルボキシ基やヒドロキシ基によって凝 集が阻害され，液中でも凝集し難い特性を有する（Kinoshita et al., 2014）。このように，本材料は高アスペクト比 の薄板状であるために，ファイバ一懸濁液などと同様の抵抗低減効果を有する可能性があり，グラフェン骨格に 由来する優れた熱伝導性と合わせて, この問題を解決出来るものと考えられる. しかしながら, 現時点で酸化グ ラフェンナノシート懸濁液の熱流動特性は十分明らかにされているとは言い難い.

よって, 本研究は酸化グラフェンナノシート懸濁液の円管内流動について, その圧力損失のみならず熱流動特 性を実験的に明らかにすることを目的とする.

\section{2. 供 試 流 体}

本研究で用いた酸化グラフェンナノシートの分子構造を図 1 に, AFM 画像およびサイズを図 2(a), (b)に示す. 酸化グラフェンナノシートは粒子形状がシート状で, 厚さが $0.8 \mathrm{~nm}$, サイズが $3 \mu \mathrm{m} \times 3 \mu \mathrm{m}$ 程度である. 供試䀣 濁液は蒸留水を用いて作製し，濃度は $0.1 \mathrm{wt} \%, 0.3 \mathrm{wt} \%, 0.5 \mathrm{wt} \%$ の 3 種類とした。供試懸濁液は実験前にミキサー でよく分散させた。比較のため, 蒸留水, 抵抗低減流体である高分子水溶液, 伝熱性能向上のための酸化チタン ナノ粒子懸濁液も用意した。高分子水溶液は Polyethylene oxide を蒸留水に溶解させたもので濃度は $15 \mathrm{ppm}$ であ る.酸化チタン粒子は直径 10-15 nm であり，濃度は $0.5 \mathrm{wt} \%$ とた。

図 3 に円錐平板型粘度計（Thermo Scientific, HAAKE RheoStress 6000）を用い測定した供試懸濁液の流動曲線を 示す. 使用した円錐の直径は $60 \mathrm{~mm}$, 角度は $1^{\circ}$ である. 図 3 中の実線は擬塑性流体の指数則流体モデル $\tau=\eta \dot{\gamma}^{n}$ である.ここで, $\tau$ はせん断応力, $\eta$ は擬塑性粘度, $\dot{\gamma}$ はせん断速度, $n$ はべき乗指数である. 図 3 中の $n$ は 0.1 wt $\% ， 0.3 \mathrm{wt} \% ， 0.5 \mathrm{wt} \%$ 対して 0.98，0.88，0.74 となった. 図4は図 3 の測定結果から得られた見掛けの粘度 $\eta_{c k}$ 
である。これらの図より，供試酸化グラフェンナノシート懸濁液は非ニュートン粘性を示し，本研究の低濃度範 囲では，その流動曲線は擬塑性流体として近似できることが分かった。一方，比較のための高分子水溶液や酸化 チタン懸濁液は水より粘度は増加したものの，非ニュートン粘性は見られなかった。

これらの結果より，流動・熱伝達特性の整理においては，供試流体の非ニュートン特性を考慮した修正レイノ ルズ数 $R e^{\prime}=8^{1-n}\left(\frac{3 n+1}{4 n}\right)^{-n}\left(\frac{\rho U^{2-n} d_{i}^{n}}{\eta}\right)$ を適用した. ここで, $\rho$ は流体の密度, $U$ は管内平均流速, $d_{i}$ は供試円管内 径である，供試懸濁液濃度の増加に伴い密度は増加するが，その変化量は本研究の濃度範囲では無視できる程度 であるため，密度は水の值を使用した。

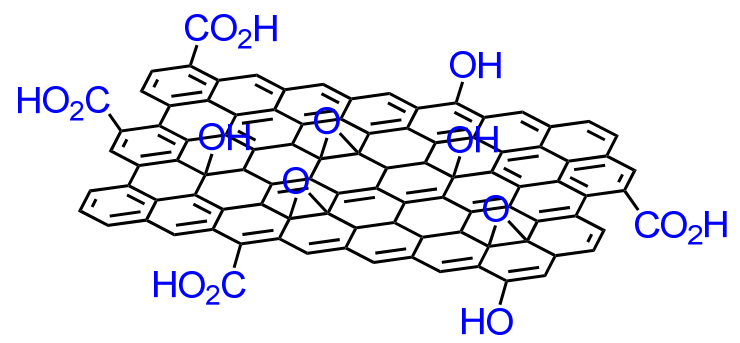

Fig. 1 Schematic model of graphene oxide.

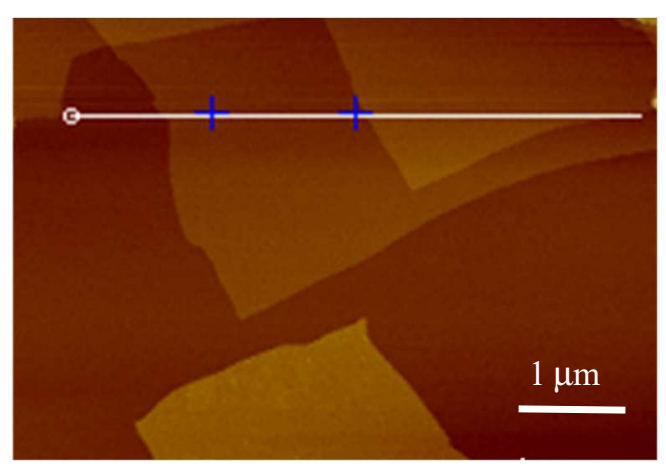

(a) AFM image

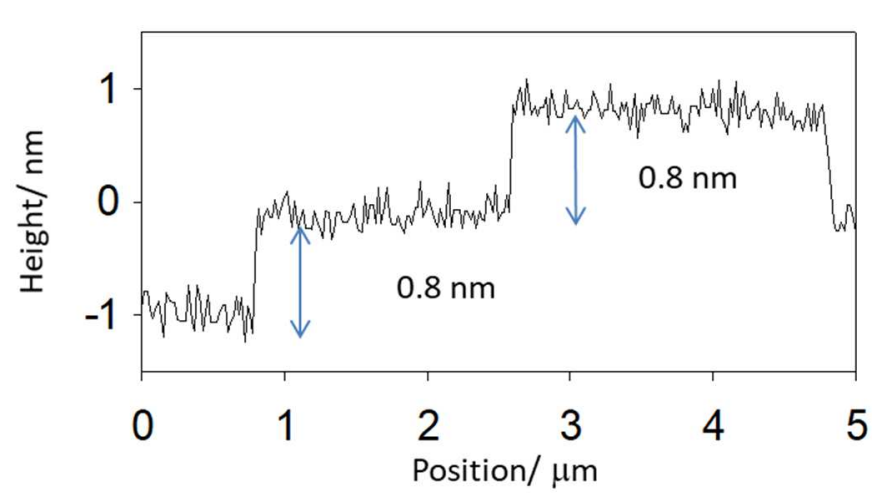

(b) Size of graphene oxide

Fig. 2 AFM image and size of graphene oxide.

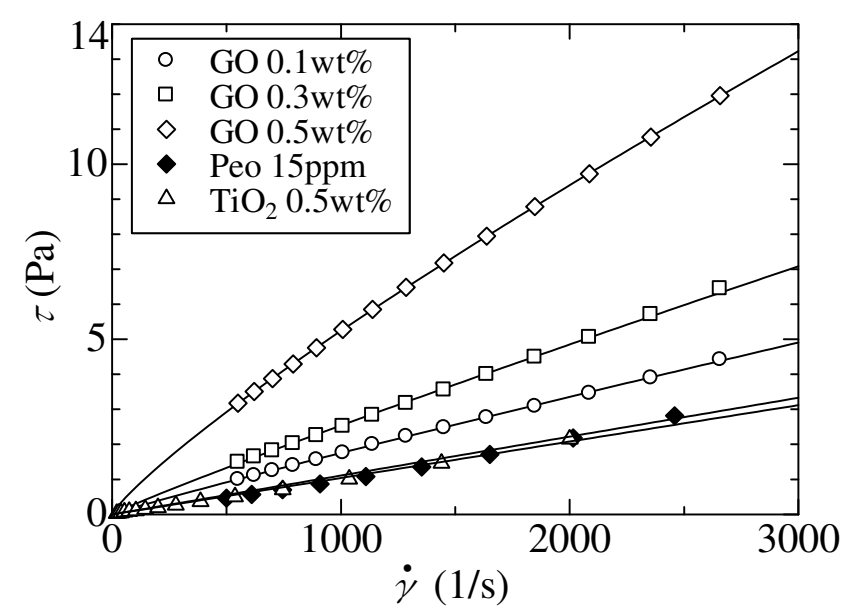

Fig. 3 Flow curve of the test fluids. The solid line denotes the power law fluid model. The graphene oxide nanosheet suspensions exhibit a non-Newtonian viscosity, and their flow curve can be approximated as a pseudoplastic fluid.

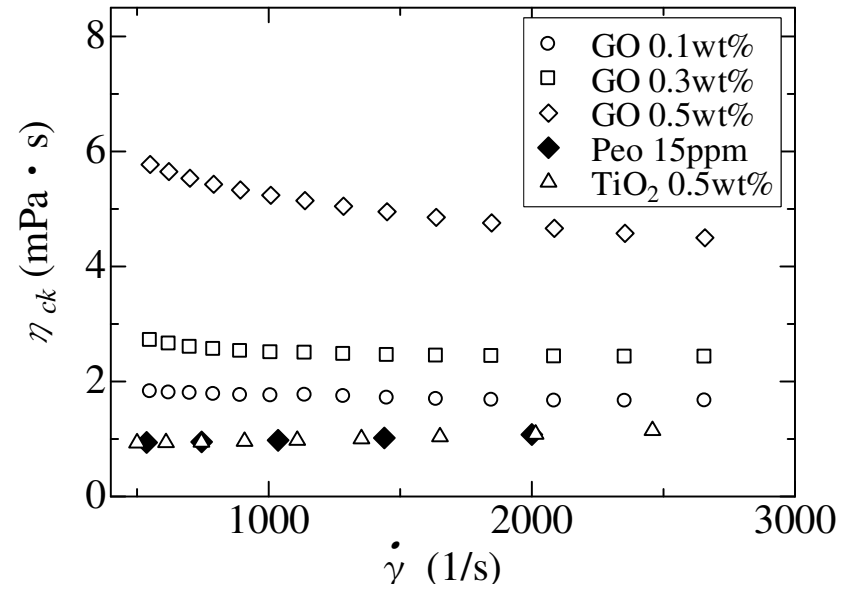

Fig. 4 Apparent viscosity of the test fluids. The graphene oxide nanosheet suspensions exhibit a non-Newtonian viscosity. The polymer solution and $\mathrm{TiO}_{2}$ suspension had higher viscosity than distilled water, but did not show a non-Newtonian viscosity. 


\section{3. 実験装置および実験方法}

供試懸濁液の圧力損失測定装置はシリンジポンプ (Nexus 6000, アイシス), シリンジおよび供試円管から構成 されている. それらは水平に接続され，流量はシリンジポンプのピストンの移動速度から求められる. 圧力損失 は圧力変換器（DP15, Validyne）で測定される. シリンジの先端に取り付けられた供試円管はステンレス鋼製で あり，内径 $d_{i}$ は $1.77 \mathrm{~mm}$ ，圧力測定区間は $150 \mathrm{~mm}$ である．助走区間は $100 \mathrm{~mm}$ に取られており，乱流域において 十分発達した流れが得られている. 本研究では, 修正レイノルズ数が $3.0 \times 10^{2}<R e^{\prime}<1.0 \times 10^{4}$ の範囲で実験を行 った. 圧力損失の測定結果に対し，(1)測定区間距離および管内径の校正に伴う誤差，(2)シリンジポンプの校正に 伴う誤差, (3)圧力変換器によるデータ収集誤差を考慮して $R e^{\prime}=3000$ の場合に対して不確かさ解析を行った結果 は，95\%包括度で不確かさは $2.98 \%$ であり，実験結果は十分な精度が得られていることが分かった。

熱伝達率測定に用いた実験装置の概略図を図 5 に示す，実験装置はシリンジポンプ，シリンジ，カートリッジ ヒーター (八光電機), 温度調節機およびデータロガーから構成され, ヒーターの中心には流路となるステンレス 鋼製の円管が通っている．供試円管の内径 $d_{i}$ は $1.99 \mathrm{~mm}$ であり，加熱区間長 $l_{h}$ は $580 \mathrm{~mm}$ である. 試験部出入口 に設置した $\mathrm{K}$ 型熱電対で入口壁面温度 $T_{w i}$ および出口壁面温度 $T_{w o}$ をそれぞれ測定した．試験部壁面は温度調節 機（TJA-550K）を用いて温度を一定に保ち，実験を行った．また， $\mathrm{T}$ 型熱電対を円管の前後に挿入することで入 口の流体温度 $T_{i}$ および出口の流体温度 $T_{o}$ をそれぞれ測定した. 測定した壁面および流体温度はデータロガー(NRTH08，キーエンス）を用いて収集した，厚さ $10 \mathrm{~mm}$ の断熱チューブを円管外側に配置しヒーターからの熱損失 を軽減した。 供試流体の温度と実験室内の温度の両方を $22^{\circ} \mathrm{C}$ し, 供試円管の壁面温度を $25^{\circ} \mathrm{C}$ に保った状態で 実験を行った。熱伝達特性の評価は式(1)で表される熱伝達率 $h$ の変化がほぼ一定となった值で行った.

$$
h=\frac{\rho c_{p} d_{i} U\left(T_{o}-T_{i}\right)}{4 l_{h} \Delta T}
$$

ここで， $c_{p}$ は供試流体の定圧比熱， $\rho$ は供試流体の密度， $\Delta T$ は次式で表される対数平均温度差である.

$$
\Delta T=\frac{\left(T_{w i}-T_{i}\right)-\left(T_{w o}-T_{o}\right)}{\ln \frac{T_{w i}-T_{i}}{T_{w o}-T_{o}}}
$$

供試懸濁液濃度の増加に伴い比熱は減少すると考えられるが, それらの変化量は本研究の濃度範囲では無視で きる程度と考えられるため, 供試䀣濁液の定圧比熱は水の值を使用した。

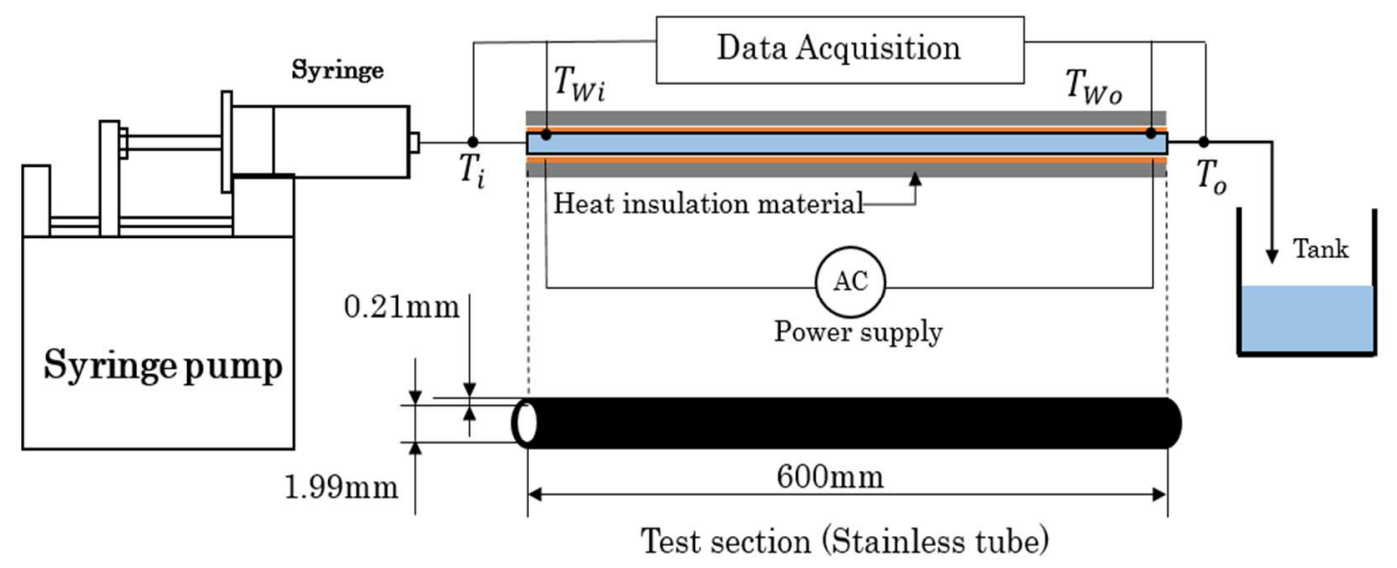

Fig. 5 Experimental apparatus of the heat transfer measurement. 


\section{4. 実 験 結 果}

\section{$4 \cdot 1$ 圧力損失}

図 6 に酸化グラフェンナノシート懸濁液 $(\mathrm{GO})$ の管摩擦係数と修正レイノルズ数 $R e$ の関係を示す. 図 6 中の実 線は円管内流れにおける層流の㛜密解 $\left(\lambda=64 / R e^{\prime}\right)$, 乱流の Blasius の式 $\left(\lambda=0.3164 R e^{-0.25}\right)$ である. 点線は非 ニュートン流体の擬塑性の影響を考慮した Dodge-Metznerの式（Dodge and Metzner, 1959）であり，以下の式で与 えられる.

$$
\frac{1}{\lambda^{1 / 2}}=\frac{2}{n^{0.75}} \log \left\{R e^{\prime} \cdot 8^{1-n} \cdot\left(\frac{\lambda}{4}\right)^{1-n / 2}\right\}-\frac{0.2}{n^{1.2}}
$$

図 6 より層流域ではすべての供試流体の管摩擦係数は層流の厳密解とよく一致していることが分かる. 一方, 乱流域において酸化グラフェンナノシート懸濁液の管摩擦係数は蒸留水と比較し減少している. そして, その減 少率は懸濁液濃度が高くなるほど増加する。この領域における高分子水溶液の管摩擦係数は蒸留水と比較し大幅

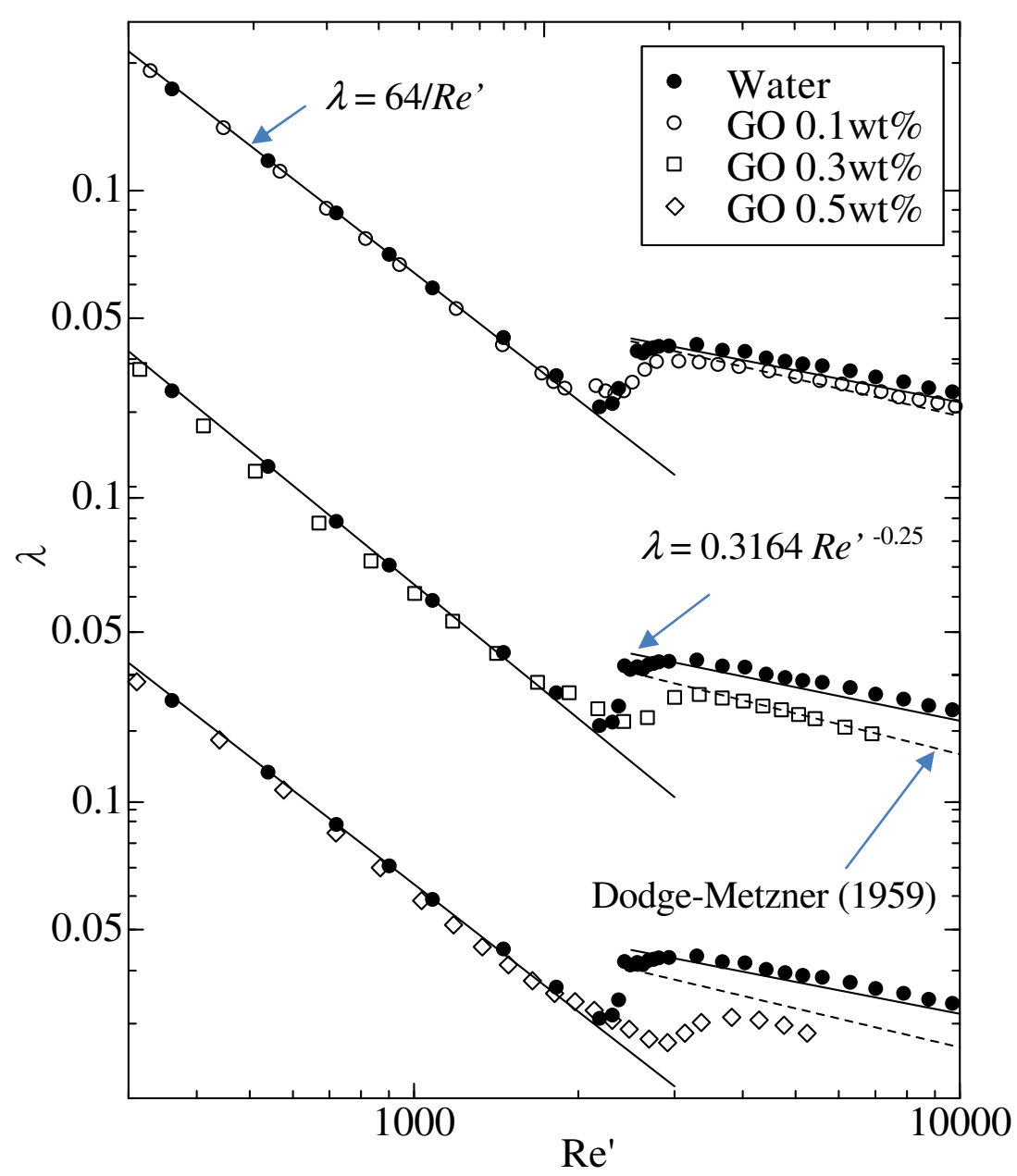

Fig. 6 Relationship between $R e^{\prime}$ and $\lambda$ for graphene oxide nanosheet suspensions. The frictional coefficient of the graphene oxide nanosheet suspensions in the turbulent region decreased compared to that of distilled water. The decrease rate increased as the suspension concentration increased. 
に減少し，Virk の最大抵抗減少漸近線（Virk and Wagger, 1989）に值が漸近した．酸化チタンの場合は乱流域で抵 抗減少効果は生ぜず，水の結果と同様にブラジウスの式と一致した。 $0.1 \mathrm{wt} \%$ (GO $0.1 \mathrm{wt} \%$ )および $0.3 \mathrm{wt} \%$ (GO $0.3 \mathrm{wt} \%)$ の酸化グラフェンナノシート懸濁液の乱流域における管摩擦係数は Dodge-Metzner の式とほぼ一致して いる．濃度が高い $0.5 \mathrm{wt} \%$ （GO 0.5 wt\%）では Dodge-Metzner の式よりも值が減少した。このことは，濃度の増加 に伴い非ニュートン流体の擬塑性のみでは，この抵抗減少効果は説明できず，擬塑性以外の効果であるグラフェ ン特有のシート状構造も抵抗減少効果のメカニズムに大きな影響を及ぼしていることが考えられる.

管摩擦係数の抵抗減少効果を定量的に評価するため, 苜留水を基準とした抵抗低減率 $D R$ を以下の式(3)によっ て定義した. その結果を図 7 に示す.

$$
D R=\frac{\lambda_{w}-\lambda}{\lambda_{w}} \times 100
$$

ここで， $\lambda$ および $\lambda_{w}$ は供試流体および蒸留水の管摩擦係数である. 図 7 より，Reが 2000 を越えた領域から抵 抗が減少し始め, $R e^{\prime}$ の増加と伴に抵抗低減率も増加した. そして, 極大值を持った後, 一定值に漸近した. それ ぞれの濃度での最大抵抗低減率は $0.1 \mathrm{wt} \%, 0.3 \mathrm{wt} \%, 0.5 \mathrm{wt} \%$ でそれぞれ $D R=19.0 \%, 24.1 \%, 36.5 \%$ となった。 一方, 従来の研究と同様に, Peo $15 \mathrm{ppm}$ 水溶液は $R e^{\prime}$ の増加に伴い $D R$ が増加し, $R e^{\prime}$ が約 8000 で最大抵抗低減 率 $D R=60 \%$ をとり, その後 $R e^{\prime}$ の増加に伴い抵抗低減率は減少している. $\mathrm{TiO}_{2} 0.5 \mathrm{wt} \%$ 懸濁液では, 抵抗が 2000 $<R e^{\prime}<3000$ で抵抗が増加するが, レイノルズ数の増加と伴に水の值に近づき, $R e^{\prime}>3000$ では抵抗低減率はゼロ

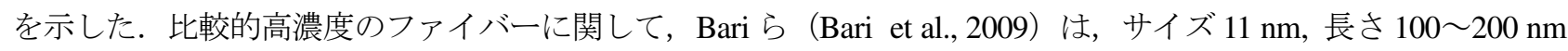
の繊維形状の Fumed Silica fiber を $600 \mathrm{ppm}$ の濃度で添加した懸濁液を用い $20000<R e<40000$ の範囲で $20 \sim 40 \%$ の抵抗減少効果を明らかにしている，高濃度の䋊維懸濁液中の繊維は絡み合いフロックを形成することで乱流渦 を減衰させる効果を有することが指摘されている，本研究で用いた酸化グラフェンナノシートは，形状は異なる が厚さ（直径）は同程度であり, それらが流体中で䋊維の絡み合いに似た構造を形成すれば乱流渦を減衰させ, 繊維懸濁液の抵抗減少効果と同様な挙動を示すことが類推できるが現時点では不明である.

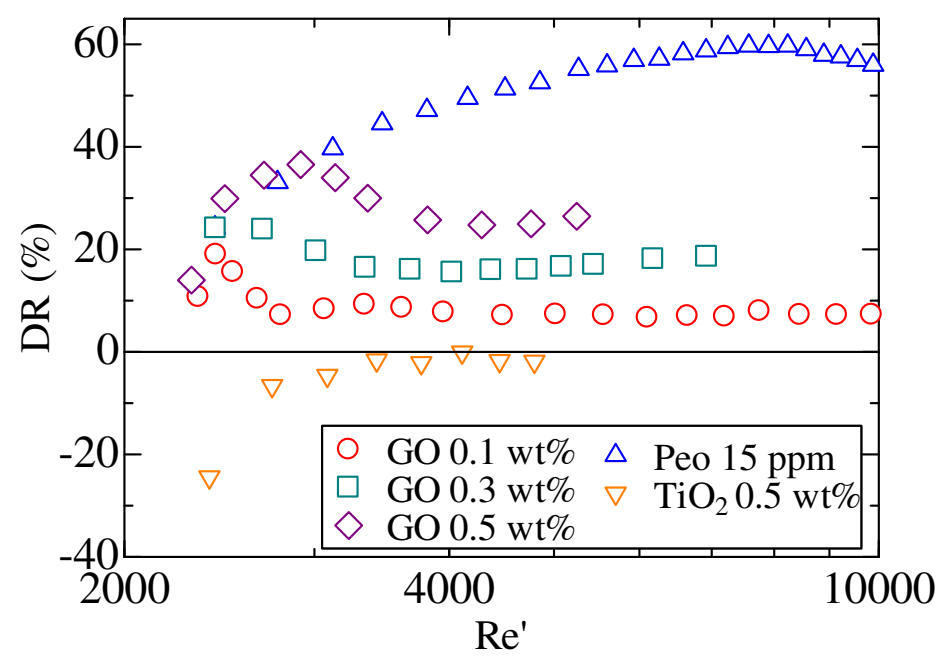

Fig. 7 Drag reduction of the graphene oxide nanosheet suspensions. The drag reduction started around $R e^{\prime}>2000$. The amount of drag reduction increased with the increase of $R e^{\prime}$. After reaching the maximum value, it gradually approached a constant value. Conversely, the drag reduction of the Peo solution greatly increased with the increase of $R e^{\prime}$. No drag reduction occurred in the $\mathrm{TiO}_{2}$ suspension. 
一方，抵抗低減添加剤の構造に関連して，Virk ら（Virk and Wagger, 1989）は添加剤による乱流域の抵抗減少効 果を溶媒のみの值と比較して平行に変化するか, そうでないかによって分類し, 前者を Type B, 後者を Type A と 分類している.この違いは微視的には添加剤の分子構造の違いによって生ずるものと考えられており, Type B は 伸張された分子や繊維で観察され，TypeA はランダムコイルの高分子などで観察される。この分類によれば, 酸 化グラフェンナノシート懸濁液の抵抗低減挙動は Type B の挙動を示すことが分かる.この Type B の抵抗減少効 果に関して, Virk ら（Virk and Wagger, 1989）は高分子濃度と抵抗低減率の関係を以下に定義される Flow enhancement $S$ をを用いて評価している.

$$
S^{\prime}=\frac{1}{\sqrt{f_{s}}}-\frac{1}{\sqrt{f_{n}}}
$$

ここで, $f$ は $f=\lambda / 4$ で与えられる円管の摩擦係数である. また，添え字の $s$ および $n$ はそれぞれ供試懸濁液およ び蒸留水を表す．図 8 に $S$ と濃度 $C_{w}$ の関係を示す。図中の左の 2 本の破線はVirk らが提案する線であり, 彼ら はバイオポリマーの值はこの 2 本の線の範囲内にあるとしている. 図中には, Type B として知られる Xanthan gum 水溶液（栃木他，2011），カーボンブラック懸濁液（渡辺他，1992）やシルク繊維懸濁液（渡辺，小方，2013）の 值も示している．比較のため, 酸化グラフェンナノシート懸濁液とカーボンブラックに対してはそれらの值をフ イティングするように Virk らの線と平行に線を引いている. 図 8 より, Xanthan gum の結果は従来の結果と一致 し Type B であることが確認できる。一方, 酸化グラフェンナノシート懸濁液の抵抗低減挙動は従来の Type B の 挙動と平行であり, 傾向は一致していることが分かる. シルクの直径は $d=64 \mu \mathrm{m}$ であり, それに対する長さの 比である $L / d$ は $L / d=13$ である. カーボンブラック懸濁液は直径約 $1.3 \mu \mathrm{m}$ の球形粒子が鎖状に連なっており, 長 さは不明であるが L/d は非常に大きいと考えられる. キサンタンガムの直径は分子サイズで L /d は非常に大きい. これらのことから, 抵抗低減を生じさせるのに必要な濃度は添加剤のサイズ (直径) に依存し, 直径の小さいも のは低濃度で効果を発揮するが，抵抗低減を生じさせるためにはサイズの増加とともに濃度を高くする必要があ ることが分かる．酸化グラフェンの厚さはキサンタンガムと同程度であるが，抵抗減少を得るには繊維懸濁液と 同程度の濃度が必要であり, 従来の傾向と一致しないことが分かる.これらの違いは酸化グラフェンが繊維状 ではなく薄板状であることによるものと考えられるが詳細は不明である。しかしながら，本結果から酸化グラフ エンナノシート懸濁液の抵抗低減は従来の伸張された分子や繊維で観察される Type B の挙動を示すことが分か った.

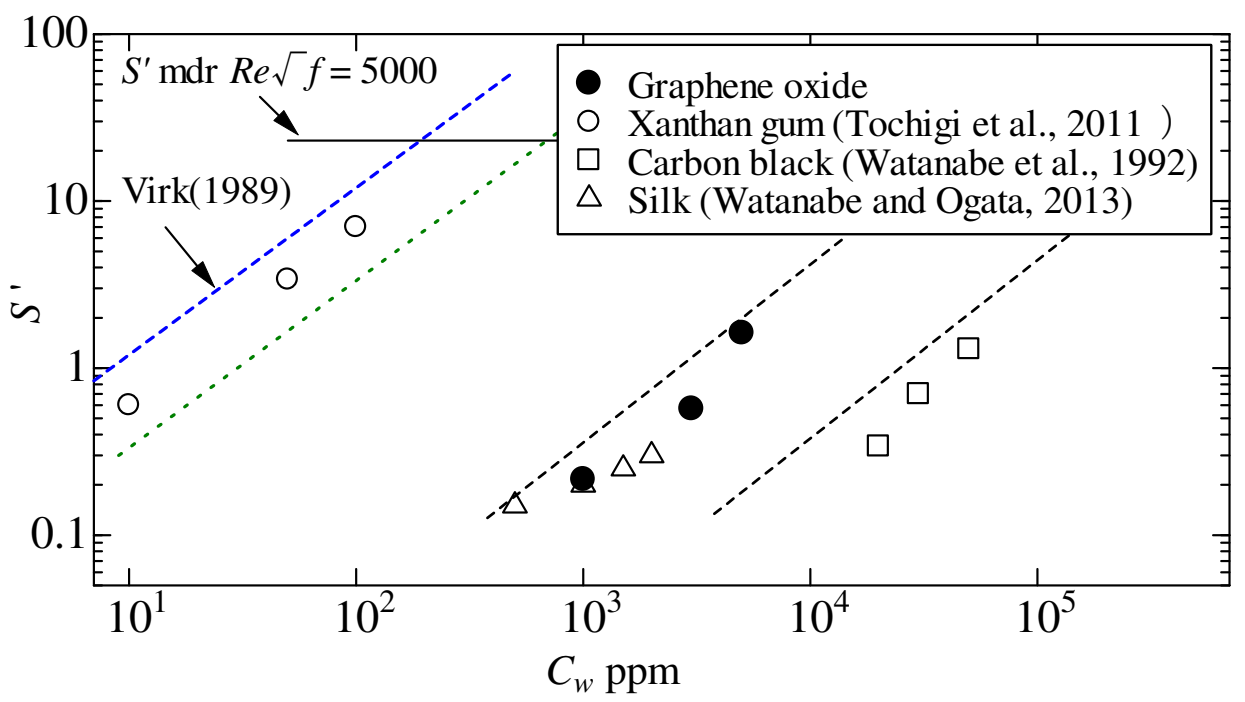

Fig. 8 Flow enhancement $S$ ' for the graphene oxide nanosheet suspensions. The dashed lines show the behavior of the Type B suspension and the values of the Xanthan gum solution, carbon black, and silk fiber suspension. The tendency of the drag reduction behavior of the graphene oxide nanosheet suspensions is consistent with that of conventional Type B suspension. 


\section{$4 \cdot 2$ 熱伝達率}

熱伝達率 $h$ を又セルト数 $N u=h d_{i} / k$ と修正レイノルズ数 $R e^{\prime}$ の関係で示した結果を図 9 に示す. 図中のエラー バーは標準偏差を表している。 ここで, $k$ は供試賏濁液の熱伝導率であり, 以下の式で与えられる Hamilton and Crosser の相関式（Murshed and Castro, 2014）を用いて求めた。

$$
k=k_{f}\left[\frac{k_{s}+(N-1) k_{f}-(N-1) V\left(k_{f}-k_{s}\right)}{k_{s}+(N-1) k_{f}+V\left(k_{f}-k_{s}\right)}\right]
$$

ここで, $k_{f}$ は単相流 (蒸留水) の熱伝導率, $k_{s}$ はナノ粒子の熱伝導率， $V$ は供試懸濁液の体積分率である. また, $N=3 / \Psi$ であり, $\Psi$ は経験的に得られた形状係数で, 本研究では $\Psi=1$ とした. 供試流体の温度が $20^{\circ} \mathrm{C}$ 時 $k_{f}=$ $0.5995 \mathrm{~W} /(\mathrm{m} \cdot \mathrm{K})$ であり, 酸化グラフェンナノシート懸濁液の熱伝導率は $0.1 \mathrm{wt} \%$ の場合で $k=0.6013 \mathrm{~W} /(\mathrm{m} ・ \mathrm{~K})$ と なった.

図 9 の実線は，以下の式(6)で与えられる円管内における十分発達した乱流での対流熱伝達式である.

$$
N u=0.027 \operatorname{Re}^{0.8} \operatorname{Pr}^{\frac{1}{3}}\left(\frac{\eta_{c k}}{\eta_{c k w}}\right)
$$

ここで， $\eta_{c k}$ は流体温度における供試流体の見掛けの粘度， $\eta_{c k w}$ は壁面温度における供試流体の見掛けの粘度，Pr は水のプラントル数である.

図 9 より，水の值は式(6)と比較して低い值となった。これは酸化グラフェンが少量しか合成出来ないことに対 応し試作した本実験装置の特性上，循環させることが出来ないため，出口温度が十分平衡になっていないことに 起因すると考えられる．このことを考慮して，本研究では同一条件の水との比較を行うことで，各供試流体の性 能の評価を行った.

図 9 より, 酸化グラフェンナノシート懸濁液の場合, エラーバーの範囲を考慮しても, すべての濃度で水と比 較的して高い熱伝達特性を示すことが分かる. そして, 懸濁液の濃度の増加に伴い熱伝達率は若干上昇する. 他 方, Peo $15 \mathrm{ppm}$ 水溶液ではヌセルト数は大きく低減し, $\mathrm{TiO}_{2} 0.5 \mathrm{wt} \%$ 懸濁液のヌセルト数は $0.1 \mathrm{wt} \%$ の酸化グラフ エンナノシート懸濁液と同程度の増加を示した.

従来の研究と同様に, 熱伝達性能の変化を蒸留水を基準とした熱伝達低減率 HTR を用い定量的に評価した結 果を図 10 に示す. HTR は式(7)で定義される.

$$
H T R=\frac{N u_{w}-N u}{N u_{w}} \times 100
$$

ここで，Nuおよび $N u_{w}$ は供試流体および蒸留水のヌセルト数である.

図 10 より, 酸化グラフェンナノシート懸濁液は, どの濃度, レイノルズ数においても熱伝達低減率が負であ り, 水よりも熱伝達特性が向上している. $0.1 \mathrm{wt} \%$ およ゙ $0.3 \mathrm{wt} \% の$ 場合, Re’゙ 3000 を超えた辺りから, 熱伝達 低減率がマイナスからゼロに近づくことから熱伝達特性の向上が減少し始め, レイノルズ数の増加と伴に熱伝達 低減率がゼロに近づいた。 それぞれの濃度での熱伝達低減率 $H T R$ の最大值は $C_{w}=0.1 \mathrm{wt} \%, 0.3 \mathrm{wt} \%, 0.5 \mathrm{wt} \%$ で それぞれ $H T R=-8.7 \%,-16.3 \%,-24.3 \%$ となり, 濃度の増加とともに熱伝達性能が向上した. 一方, Peo 水溶液は, 従来の結果（Li et al., 2004,2012）と同様に，乱流域において最大約 50\%の熱伝達性能低下が確認された。これは 抵抗低減率と同程度であることが分かる． $\mathrm{TiO}_{2}$ 懸濁液は，従来の結果（Ganvir et al., 2017）と同様に熱伝達性能が 向上している. それは最大で約 $9.7 \%$ あった. 


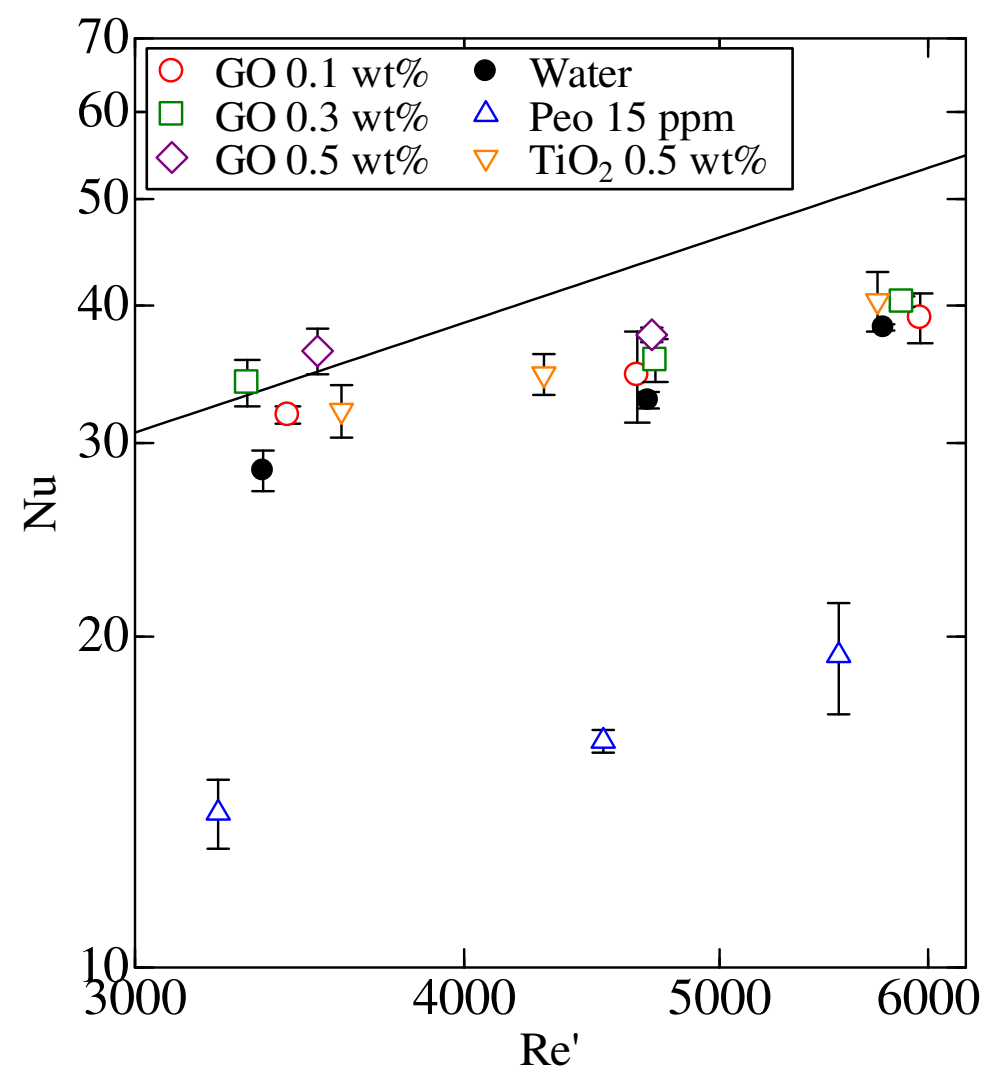

Fig. 9 Relationship between $R e^{\prime}$ and $N u$. The Nusselt number of the graphene oxide nanosheet suspensions increased compared to that of distilled water and slightly increased with the concentration of the suspension. The Nusselt number of the Peo solution was greatly reduced, while that of the $\mathrm{TiO}_{2}$ suspension increased as much as that of the $0.1 \mathrm{wt} \%$ graphene oxide nanosheet suspension.

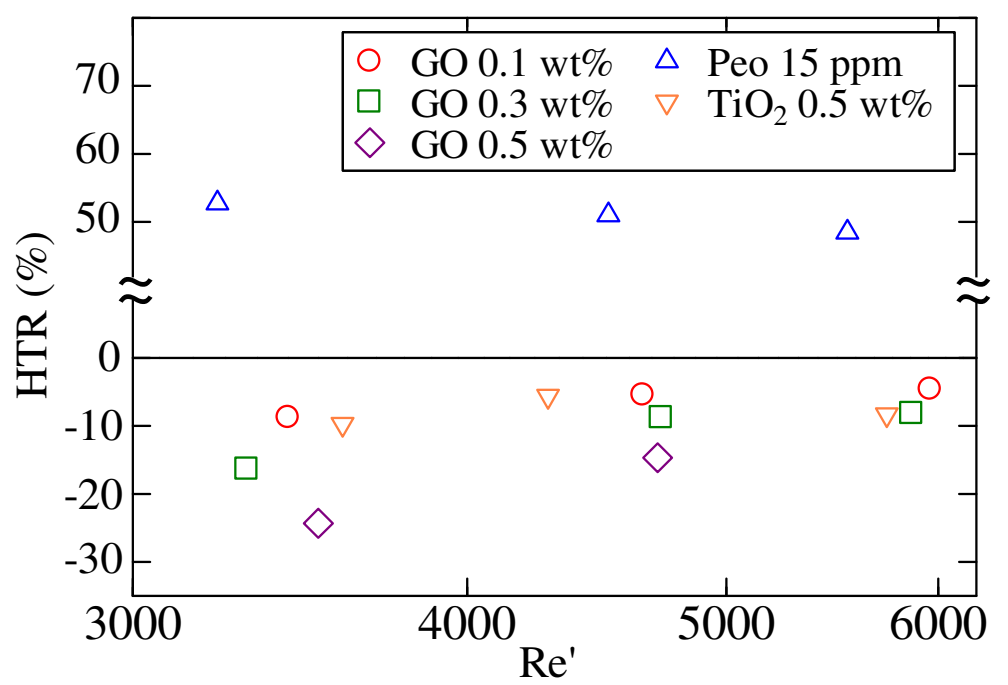

Fig. 10 Heat transfer reduction for the graphene oxide nanosheet suspensions. The heat transfer reduction of the graphene oxide nanosheet suspensions began to decrease at around $R e^{\prime}>3000$ and approached zero with an increase in the Reynolds number. 


\section{$4 \cdot 3$ 熱伝達率と抵抗低減の相関}

抵抗低減率と熱伝達低減率のアナロジーを評価するために，図 11 に両者の值を同時にプロットした結果を示 す. 図 11 は横軸を $H T R$, 縦軸を $D R$ としており, 第 1 象限は抵抗低減は生じるが同時に熱伝達率も減少すること を示し, 従来の抵抗低減流体はこの領域に存在する.熱伝達性能を向上させる効果を有する一般的なナノ流体は, 第 3 象限もしくは負の $y$ 軸上にプロットされる. 一方，第 2 象限は抵抗低減と熱伝達性能の同時達成を示してい る.

図 11 より明らかなように，本研究で用いた酸化グラフェンナノシート眯濁液の実験結果は第 2 象限にあり，抵 抗低減と熱伝達率性能向上を同時に達成していることが分かる．また，両者はほぼ線形関係にあり，抵抗低減量 の増加とともに熱伝達性能も増加する。当然のことながら, 抵抗低減効果を生じない $\mathrm{TiO}_{2}$ 䀣濁液は, 第 3 象限も しくは負の $y$ 軸上にプロットされている. これらは従来の実験結果と良く一致した. 一方, 熱伝達性能が悪化し た Peo 水溶液は第 1 象限にあり，抵抗低減効果は大きいがその効果を発揮しているレイノルズ数において，それ と同程度の熱伝達低下が生じる，以上のことにより，酸化グラフェンナノシート懸濁液は流れの乱れ抑制効果に 加えて，熱伝導率の高いグラフェンによる有効熱伝導率の向上，粒子の熱運動なども合わせて熱伝導率の向上の 効果があると指摘出来る。これらの結果から，供試酸化グラフェンナノシート懸濁液は，これまで両立困難と考 えられてきた抵抗低減と熱伝達増加の両方の特性を有することが示された。

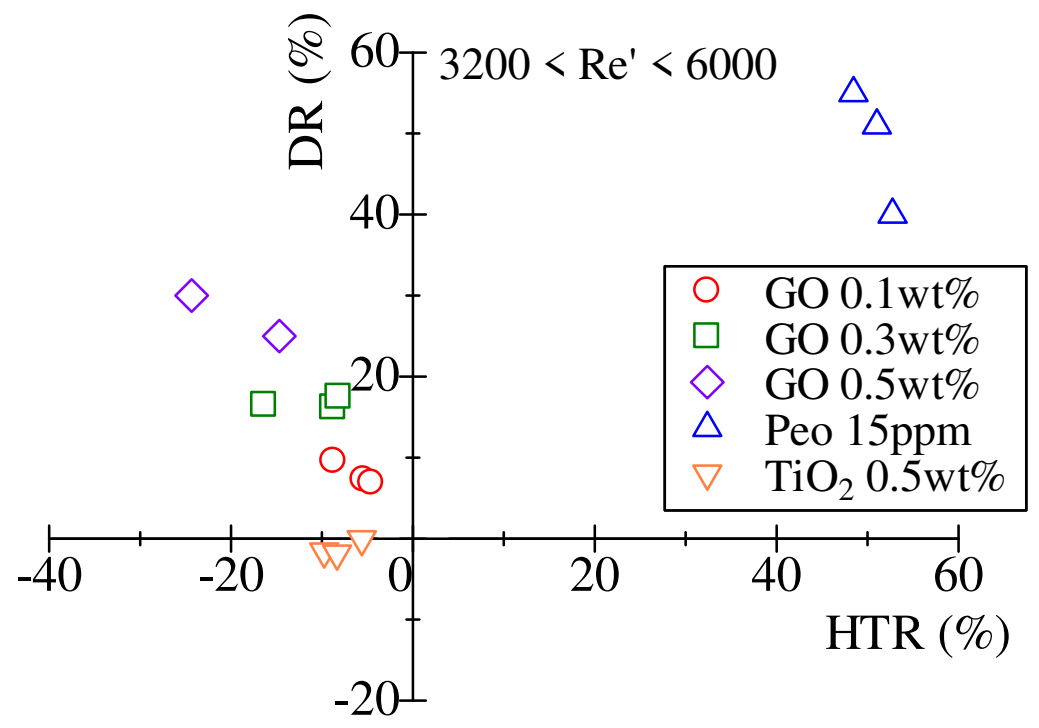

Fig. 11 Analogy of the drag reduction and heat transfer reduction. The experimental results of the graphene oxide nanosheet suspensions are in the 2nd quadrant. Resistance reduction and improvement of the heat transfer performance were achieved. The relationship between the two was linear; therefore, the heat transfer performance increased as the resistance reduction increased. The $\mathrm{TiO}_{2}$ suspension, which did not produce a drag reduction effect, is in the third quadrant. The Peo solution, whose heat transfer performance deteriorated, is in the first quadrant.

\section{5. 結言}

$0.1 \mathrm{wt} \% ， 0.3 \mathrm{wt} \% ， 0.5 \mathrm{wt} \%$ の酸化グラフェンナノシート懸濁液を用いて，円管内圧力損失測定および熱伝達率 測定を行った. 比較のため $\mathrm{TiO}_{2} 0.5 \mathrm{wt} \%$ 懸濁液および Peo $15 \mathrm{ppm}$ 水溶液でも同様の実験を行った.

本研究の結果, $0.8 \mathrm{~nm} \times 3 \mu \mathrm{m} \times 3 \mu \mathrm{m}$ のサイズを有する酸化グラフェンナノシート懸濁液は乱流域で蒸留水と比 較して管摩擦係数が最大 $36.5 \%$ 低減する抵抗減少効果を明らかにした。この効果はレイノルズ数の増加に伴い極 大值を示した後, 一定值となる挙動を示した。一方，抵抗減少効果が生じるレイノルズ数範囲で酸化グラフェン ナノシート懸濁液のヌセルト数は 10 - $20 \%$ 上昇し伝熱性能が向上することが分かった. この伝熱性能は本レイノ ルズ数範囲では濃度およびレイノルズ数の増加とともに上昇した. 比較のために行った $\mathrm{TiO}_{2} 0.5 \mathrm{wt} \%$ 懸濁液およ びPeo $15 \mathrm{ppm}$ 水溶液においては, 従来から指摘されているように抵抗低減と熱伝達向上を両立させることは不可 能であった。熱伝達率と抵抗低減の相関から, 本研究で用いた酸化グラフェンナノシート䀣濁液はこれらの特性 を伴に有していることが明らかにされた。 
謝 辞

本研究は JSPS KAKENHI No. 19K04196 の助成を受けたものである．また，本研究の実験データの一部は首都 大学東京大学院博士前期課程の院生であった山本晃平氏, 三富崇大氏によって取得された. ここに感謝の意を表 する.

\section{文献}

Bari, H.A.A., Suali, E. and Hassan, Z., Fumed silica fiber as a new drag reducing agent for aqueous medias flowing through pipelines, Canadian Journal of pure \& applied sciences, Vol. 3, No. 1 (2009), pp. 755-758.

Bhanvase, B.A., Sarode, M. R., Putterwar, L.A., Abdullah, K.A., Deosarkar, M.P. and Sonawane, S.H., Intensification of convective feat transfer in water/ethylene glycol based nanofluids containing $\mathrm{TiO}_{2}$ nanoparticles, Chemical Engineering and Processing, Vol. 82 (2014), pp. 123-131.

Cui, H. and Grace, J.R., Flow of pulp fibre suspension and slurries: a review, International Journal of Multiphase Flow, Vol. 33, No. 9 (2007), pp. 921-934.

Dodge, D.W. and Metzner, A.B., Turbulent flow of non-Newtonian systems, AIChE Journal, Vol. 5, No. 2 (1959), pp. 189-204.

Gasljevic, K. and Matthys, E.F., Field test of drag-reducing surfactant additives in a hydraulic cooling system, Proceedings of ASME Fluid Engineering Division Summer Meeting, Vol. FED-237 (1996), pp. 249-260.

Ganvir, R.B., Walke, P.V. and Kriplani, V.M., Heat transfer characteristics in nanofluid - a review, Renewable and Sustainable Energy Reviews, Vol. 75 (2017), pp. 451-460.

Kinoshita, H., Nishina, Y., Alias, A.A. and Fujii, M., Tribological properties of monolayer graphene oxide sheets as water-based lubricant additives, Carbon, Vol. 66 (2014), pp. 720-723.

Li, F.-C., Kawaguchi, Y. and Hishida, K., Investigation on the characteristics of turbulence transport for momentum and heat in a drag-reducing surfactant solution flow, Physics of Fluids, Vol. 16 (2004), pp. 3281-3295.

Li, F.-C., Yu, B., Wei, J.J. and Kawaguchi, Y., Turbulent drag reduction by surfactant additives, Wiley (2012), ISBN-13: 9781118181072.

Murshed, S.M.S. and Castro, C.A.N., Superior thermal features of carbon nanotubes-based nano-fluids - a review, Renewable and Sustainable Energy Reviews, Vol. 37 (2014), pp. 155-167.

Sarafraz, M.M. and Hormozi, F., Heat transfer, pressure drop and fouling studies of multi-walled carbon nanotube nano-fluids inside a plate heat exchanger, Experimental Thermal and Fluid Science, Vol. 72 (2016), pp. 1-11.

Shi, H., Ge, W., Oh, H., Pattison, S.M., Huggins, J.T., Talmon, Y., Hart, D.J., Raghavan, S.R. and Zakin, J.L., Photoreversible micellar solution as a smart drag-reducing fluid for use in district heating/cooling systems, Langmuir, Vol. 29, No. 1 (2013), pp. 102-109.

栃木弘, 中村大吾, 小方聡, 渡辺敬三, バイオポリマー水溶液の抵抗減少効果に関する研究（第 1 報 キサンタン ガム水溶液の流動の特性），日本機械学会 2011 年度年次大会講演論文集 (2011), S055021.

Toms, B.A., Some observation on the flow of linear polymer solutions through straight tubes at large Reynolds numbers, Proceedings of First International Congress on Rheology, Vol. 2 (1949), pp. 135-141.

Virk, P.S., Mickley, H.S. and Smith, K.A., The ultimate asymptote and mean flow structure in Tom's phenomenon, Journal of Applied Mechanics, Vol. 37 (1970), pp. 488-493.

Virk, P.S. and Wagger, D.L., Aspects of mechanisms in type B drag reduction, structure of turbulence and drag reduction, Springer (1989), pp. 201-213.

Wang, P.Y., Wang, X.J. and Liu, Z.H., Flow drag and heat transfer characteristics of drag-reducing nanofluids with $\mathrm{CuO}$ nanoparticles, Heat Mass Transfer, Vo. 53, No. 2 (2017), pp. 377-385.

White, C.M. and Mungal, M.G., Mechanics and prediction of turbulent drag reduction with polymer additives, Annual Review of Fluid Mechanics, Vol. 40 (2008), pp. 235-256.

渡辺敬三, 大平浩之, 加藤宏, 水-微細固体粒子懸濁液の抵抗減少効果, 日本機械学会論文集 B 編, Vol. 58, No. 548 (1992), pp. 1056-1062.

渡辺敬三, 小方聡, バイオ緘維懸濁液の抵抗減少効果, 日本機械学会 2013 年度年次大会講演論文集 (2013), S051035.

Zakin, J.L., Lu, B. and Bewersdorff, H.-W., Surfactant drag reduction, Reviews in Chemical Engineering, Vol. 14 (1998), pp. 253-320. 


\section{References}

Bari, H.A.A., Suali, E. and Hassan, Z., Fumed silica fiber as a new drag reducing agent for aqueous medias flowing through pipelines, Canadian Journal of pure \& applied sciences, Vol. 3, No. 1 (2009), pp. 755-758.

Bhanvase, B.A., Sarode, M. R., Putterwar, L.A., Abdullah, K.A., Deosarkar, M.P. and Sonawane, S.H., Intensification of convective feat transfer in water/ethylene glycol based nanofluids containing $\mathrm{TiO}_{2}$ nanoparticles, Chemical Engineering and Processing, Vol. 82 (2014), pp. 123-131.

Cui, H. and Grace, J.R., Flow of pulp fibre suspension and slurries: a review, International Journal of Multiphase Flow, Vol. 33, No. 9 (2007), pp. 921-934.

Dodge, D.W. and Metzner, A.B., Turbulent flow of non-Newtonian systems, AIChE Journal, Vol. 5, No. 2 (1959), pp. 189-204.

Gasljevic, K. and Matthys, E.F., Field test of drag-reducing surfactant additives in a hydraulic cooling system, Proceedings of ASME Fluid Engineering Division Summer Meeting, Vol. FED-237 (1996), pp. 249-260.

Ganvir, R.B., Walke, P.V. and Kriplani, V.M., Heat transfer characteristics in nanofluid - a review, Renewable and Sustainable Energy Reviews, Vol. 75 (2017), pp. 451-460.

Kinoshita, H., Nishina, Y., Alias, A.A. and Fujii, M., Tribological properties of monolayer graphene oxide sheets as water-based lubricant additives, Carbon, Vol. 66 (2014), pp. 720-723.

Li, F.-C., Kawaguchi, Y. and Hishida, K., Investigation on the characteristics of turbulence transport for momentum and heat in a drag-reducing surfactant solution flow, Physics of Fluids, Vol. 16 (2004), pp. 3281-3295.

Li, F.-C., Yu, B., Wei, J.J. and Kawaguchi, Y., Turbulent drag reduction by surfactant additives, Wiley (2012), ISBN-13: 9781118181072.

Murshed, S.M.S. and Castro, C.A.N., Superior thermal features of carbon nanotubes-based nano-fluids - a review, Renewable and Sustainable Energy Reviews, Vol. 37 (2014), pp. 155-167.

Sarafraz, M.M. and Hormozi, F., Heat transfer, pressure drop and fouling studies of multi-walled carbon nanotube nano-fluids inside a plate heat exchanger, Experimental Thermal and Fluid Science, Vol. 72 (2016), pp. 1-11.

Shi, H., Ge, W., Oh, H., Pattison, S.M., Huggins, J.T., Talmon, Y., Hart, D.J., Raghavan, S.R. and Zakin, J.L., Photoreversible micellar solution as a smart drag-reducing fluid for use in district heating/cooling systems, Langmuir, Vol. 29, No. 1 (2013), pp. 102-109.

Tochigi, H., Nakamura, D., Ogata, S. and Watanabe, K., Drag reduction of biopolymer solutions: 1st. report, flow characteristics of xanthan gum solutions in a circular pipe, Proceedings of the Mechanical Engineering Congress (2011), S055021 (in Japanese).

Toms, B.A., Some observation on the flow of linear polymer solutions through straight tubes at large Reynolds numbers, Proceedings of First International Congress on Rheology, Vol. 2 (1949), pp. 135-141.

Virk, P.S., Mickley, H.S. and Smith, K.A., The ultimate asymptote and mean flow structure in Tom's phenomenon, Journal of Applied Mechanics, Vol. 37 (1970), pp. 488-493.

Virk, P.S. and Wagger, D.L., Aspects of mechanisms in type B drag reduction, structure of turbulence and drag reduction, Springer (1989), pp. 201-213.

Wang, P.Y., Wang, X. J. and Liu, Z. H., Flow drag and heat transfer characteristics of drag-reducing nanofluids with $\mathrm{CuO}$ nanoparticles, Heat Mass Transfer, Vo. 53, No. 2 (2017), pp. 377-385.

White, C.M. and Mungal, M.G., Mechanics and prediction of turbulent drag reduction with polymer additives, Annual Review of Fluid Mechanics, Vol. 40 (2008), pp. 235-256.

Watanabe, K., Ohira, H. and Kato, H., Drag reduction phenomenon in water/fine solid particle suspension, Transactions of the Japan Society of Mechanical Engineers, Series B, Vol. 58, No. 548 (1992), pp. 1056-1062 (in Japanese).

Watanabe, K. and Ogata, S., Drag reduction bio-fiber suspensions, Proceedings of the Mechanical Engineering Congress (2013), S051035 (in Japanese).

Zakin, J.L., Lu, B. and Bewersdorff, H.-W., Surfactant drag reduction, Reviews in Chemical Engineering, Vol. 14 (1998), pp. 253-320. 